\title{
A Possible Role of Serum Soluble TNF-related Apoptosis-Inducing Ligand (TRAIL) in Pathogenesis of Systemic Lupus Erythematosus
}

\author{
Mamdouh Abadier \& Faysal Omran* \\ Departments of Medical Biochemistry \& Rheumatology*, \\ Faculty of Medicine, Benha University
}

\begin{abstract}
The present study aimed to estimate the serum levels of soluble tumor necrosis factorrelated apoptosis-inducing ligand (sTRAIL) in patients with systemic lupus erythematosus (SLE) and to compare these levels to that estimated in patients with other autoimmune diseases and to control levels. The study included 50 patients with SLE underwent clinical and laboratory evaluation. Disease activity was determined according to the SLE disease activity index (SLEDAI score; $\leq 4$ : inactive \& $>4$ : active disease). The study also included 30 patients with diagnosed rheumatoid arthritis $(R A, n=15)$ and Wegener's granulomatosis $(W G, n=15)$ and 10 healthy volunteers as control group. All study participants gave blood samples for ELISA estimation of serum STRAIL concentration. The Clinical evaluation of SLE patients defined 27 patients with inactive and 23 patients with active SLE with mean SLEDAI score of $2 \pm 0.2$ and $9.96 \pm 0.63$, respectively. Mean blood levels of C3 and C4 were significantly $(p<0.001)$ decreased, while mean CRP level and anti-dsDNA antibodies levels were significantly $(p<0.001)$ higher in patients with active SLE compared to those with inactive disease. Also, both total and differential leucocytic counts were significantly lower in patients with active compared to those with quiescent disease and 5 patients were neutropenic. Mean serum levels of STRAIL were significantly higher in SLE patients, irrespective to the disease activity compared to serum levels estimated in controls $\left(P_{1}=0.005\right)$ and in $R A$ and $W G$ patients $\left(P_{2} \& P_{3}=0.001\right)$. On contrary, serum sTRAIL levels estimated in RA and $W G$ were non-significantly higher compared to control level $\left(P_{1}>0.05\right)$, also with a non-significantly higher levels in $R A$ patients compared to levels estimated in WG patients $\left(P_{2}>0.005\right)$. Patients with inactive SLE had a significantly $\left(P_{4}=0.002\right)$ higher serum levels of STRAIL compared to levels estimated in patients with active SLE. Serum STRAIL showed a negative significant correlation with SLEDAI score and laboratory parameters of SLE activity. Conclusion: It could be concluded that TRAIL has a possible role in pathogenesis and initiation of activity of SLE and estimation of serum STRAIL could be used as a specific marker for differentiation between SLE from other autoimmune diseases and between patients with active and inactive disease.
\end{abstract}

Key wards: Systemic lupus erythematosus, serum, sTRAIL 


\section{INTRODUCTION}

Apoptosis (programmed cell death) is an active physiological process that leads to the ordered destruction of cells without the release of intracellular contents which would cause an inflammatory reaction and tissue damage into the extracellular environment. It is fundamental to maturation and homeostasis of the immune system. Apoptosis can be induced passively, through lack of essential survival signals, or actively, through ligand induced trimerization of specific death receptors of the tumor necrosis factor (TNF) receptor family, such as Fas, the TNF receptor, or the TNF related apoptosis inducing ligand receptor ${ }^{(\mathbf{1})}$.

TNF-related apoptosis-inducing ligand (TRAIL, APO-2 ligand) is a transmembrane (type II) glycoprotein $^{(2)}$. The extracellular domain of TRAIL is homologous to that of other TNF superfamily members and shows a homotrimeric subunit structure. Like TNF and FasL, TRAIL also exists physiologically in a biologically active soluble homotrimeric form ${ }^{(3)}$.

TRAIL can interact with five different receptors, namely two agonistic receptors called DR4/TRAIL-R1 and DR5/TRAIL-R2 (referred to as TRAIL-R1 and -R2, respectively), two membraneanchored decoy receptors designated DcR1/TRAIL-R3 and DcR2/TRAILR4 (referred to as TRAIL-R3, and $\mathrm{R} 4$, respectively), and a soluble decoy receptor known as osteoprotegerin $(\mathrm{OPG})^{(\mathbf{4})}$. The affinities of TRAIL-R3 and -R4 for TRAIL at physiological temperatures are 50-100-fold lower than those between TRAIL and its cognate receptors TRAIL-R1 and $\mathrm{R} 2^{(5)}$.

TRAIL triggers apoptosis through interaction with the death receptors TRAIL-R1 and -R2 that contain a cytoplasmic death domain and can induce apoptosis through the activation of caspases upon ligation with a TRAIL ligand. Nevertheless, the binding of TRAIL to these TRAIL receptors can also activate the transcription factor $\mathrm{NF} \kappa \mathrm{B}$, which is known to control cell proliferation ${ }^{(6)}$. Indeed, although TRAIL is known to induce apoptosis in tumor cells, TRAIL has also been shown to promote endothelial cell proliferation $^{(7)}$. Thus, depending on the cellular system, TRAIL is capable of initiating apoptosis or cell survival $^{(8)}$.

There are several indications that TRAIL could be involved in the pathophysiology of autoimmune diseases in general and SLE in particular. In patients with multiple sclerosis, FasL and TRAIL are upregulated in peripheral blood mononuclear cells ${ }^{(9)}$. In patients with Sjögren's syndrome TRAIL-R1 and TRAIL-R2 are strongly expressed on the ductal epithelial cells in the salivary glands ${ }^{(10)}$. Kaplan et al. ${ }^{(11)}$ reported that increased expression of TRAIL and FasL on activated T cells contributes to increased monocyte apoptosis in patients with SLE. Furthermore increased mRNA for TRAIL and its decoy receptors (TRAIL-R3 and -R4) was found in peripheral blood mononuclear cells from SLE patients ${ }^{(\mathbf{1 2})}$. 
Systemic lupus erythematosus is a disorder of generalized autoimmune disease that may affect different organ systems, including the skin, joints, central and peripheral nervous system, kidneys, and liver. SLE is characterized by pathogenic autoantibodies and immune complexes that are attributed to inappropriate regulation of hyperactivated $B$ and $T$ cells, defective clearance of apoptotic cells and immune complexes, and loss of immune tolerance ${ }^{(\mathbf{1 3})}$. The presence of autoantibodies, especially those directed to double stranded DNA, is characteristic of the disease. The role of $T$ cells in the pathogenesis of SLE is revealed by a defect of T-cellmediated immunological tolerance and by their support of autoantibody production by autoantigen-reactive $B$ cells $^{(\mathbf{1 4})}$. The aetiology of SLE is complex. Multiple susceptibility genes and environmental factors are implicated in the initiation and perpetuation of the activation of $\mathrm{T}$ and B lymphocytes. Also, Spontaneous remission or improvements in the course of the disease are common in patients with $\operatorname{SLE}^{(\mathbf{1 3})}$.

This study aimed to estimate the serum levels of soluble TRAIL in patients with SLE and to compare these levels to that estimated in patients with other autoimmune diseases and to control levels.

\section{PATIENTS \& METHODS}

The present study was conducted at Rheumatology and Medical Biochemistry Departments, Faculty of Medicine, Benha University. The study included 50 patients with SLE. Disease activity was determined according to the SLE disease activity index (SLEDAI score). The SLEDAI score was calculated and patients with quiescent or inactive disease were defined as the persistent absence of disease activity (SLEDAI score $\leq 4$ ) for at least 4 months with no or on constant dose of an immunomodulating agent ${ }^{(15)}$. SLE patients underwent laboratory assessment of serum levels of $\mathrm{C} 3, \mathrm{C} 4, \mathrm{C}$ reactive protein (CRP) and leucocyte, neutrophil, monocyte and lymphocyte counts. Patients whose absolute blood neutrophil counts (ANC) were below $1.5 \times 10^{3} / \mu$ l were diagnosed as having neutropenia ${ }^{(\mathbf{1 6})}$. Antibodies aganist dsDNA were measured by Farr assay according to manufacturer's instructions ${ }^{(17)}$.

To evaluate serum soluble TRAIL (sTRAIL) the study included 15 patients diagnosed as rheumatoid arthritis (RA) and another 15 patients diagnosed as Wegener's granulomatosis (WG). The study also included 10 healthy volunteers considered as control group.

All study participants gave venous blood samples that were allowed to clot and centrifuged to separate serum which is kept frozen at $-80^{\circ} \mathrm{C}$ till assayed for sTRAIL concentration using ELISA technique as follows: a monoclonal antibody specific for sTRAIL was coated onto the wells of the microtitre strips. An aliquot of $100 \mu \mathrm{l}$ of undiluted serum was pipetted in duplicate into the wells. During the first incubation, the sTRAIL antigen and a biotinylated monoclonal antibody specific for sTRAIL were simultaneously incubated for three hours at room temperature $\quad\left(18-25^{\circ} \mathrm{C}\right)$. After 
washing, the enzyme streptavidin-poly horseradish peroxidase was added. After incubation for 30 minutes and washing to remove unbound enzyme, a substrate solution was added to the bound enzyme to induce a coloured reaction product. The optical density (OD), reflecting the intensity of the product, was measured using spectrophotometer at $450 \mathrm{~nm}$ as the primary wavelength and $650 \mathrm{~nm}$ as the reference wavelength. Linear calibration curves were made using standard TRAIL $(0-3000 \mathrm{pg} / \mathrm{ml})$, provided with the kit. The amount of sTRAIL in the serum samples was determined by extrapolating OD values to TRAIL concentrations using the calibration curves. The minimum detectable dose was $64 \mathrm{pg} / \mathrm{ml}$. The ELISA was found to be specific for TRAIL; cross reactivity with TNF- $\alpha$ was absent and the signal could be blocked specifically by the addition of soluble TRAIL receptors ${ }^{(18)}$.

\section{Statistical analysis}

Obtained data were presented as mean $\pm \mathrm{SD}$, ranges, numbers and ratios. Results were analyzed using paired Ztest and Chi-square test. Possible relationships were investigated using Pearson linear regression. Statistical analysis was conducted using the SPSS (Version 10, 2002) for Windows statistical package. $\mathrm{P}$ value $<0.05$ was considered statistically significant.

\section{RESULTS}

The study included 50 SLE patients; 39 females and 11 males with mean age of $45.6 \pm 12.3$; range: 15-72 years and 15 patients with RA; 11 females and 4 males with mean age of 45.3 \pm 8.2 ; range: $29-59$ and 15 patients with WG; 10 females and 5 males with mean age of $41.6 \pm 12.5$; range: $24-63$ years. There was a nonsignificant difference between studied patients as regards age and sex distribution. Also, 10 control subjects; 7 females and 3 males with mean age of $42.7 \pm 13$; range: $26-67$ years were enrolled in the study.

Clinical evaluation of SLE patients using SLEDAI score defined 27 patients with inactive disease with mean SLEDAI score of $2 \pm 0.2$; range: 1.5-2.2 and 23 patients with active disease with mean SLEDAI score of 9.96 \pm 0.63 ; range: $8.9-11$. There was a non-significant difference between patients with active and inactive SLE as regards age and sex distribution.

Mean blood levels of $\mathrm{C} 3$ and $\mathrm{C} 4$ were significantly $\quad(\mathrm{p}<0.001)$ decreased in patients with active SLE compared to those with inactive disease. Also, both total and differential leucocytic counts were significantly lower in patients with active compared to those with quiescent disease and 5 patients; 3 had active disease and 2 had inactive disease were neutropenic. On contrary, mean CRP level and antidsDNA antibodies levels were significantly $(p<0.001)$ higher in patients with active disease (Table 1).

Mean serum levels of sTRAIL were significantly higher in SLE patients, irrespective to the disease activity compared to serum levels estimated in controls $\left(\mathrm{P}_{1}=0.005\right)$ and in $\mathrm{RA}$ and $\mathrm{WG}$ patients $\left(\mathrm{P}_{2} \&\right.$ $\left.\mathrm{P}_{3}=0.001\right)$. On contrary, serum STRAIL levels estimated in RA and WG were non-significantly higher compared to control level $\left(\mathrm{P}_{1}>0.05\right)$ 
with a non-significantly higher levels in RA patients compared to levels estimated in WG patients $\left(\mathrm{P}_{2}>0.005\right)$. Patients with inactive SLE had a significantly $\left(\mathrm{P}_{4}=0.002\right)$ higher serum levels of sTRAIL compared to levels estimated in patients with active SLE, (Table 2, Fig. 1). Serum sTRAIL showed a negative significant correlation with SLEDAI score and laboratory parameters of SLE activity (Table 3, Fig. 2).

Table (1): Mean $( \pm$ SD) of estimated laboratory parameters in SLE patients categorized disease according to activity based on SLEDAI score

\begin{tabular}{l|cccc}
\hline \multirow{2}{*}{ Parameter } & $\begin{array}{c}\text { Inactive } \\
\boldsymbol{S L E}\end{array}$ & $\begin{array}{c}\text { Active } \boldsymbol{S L E} \\
(\boldsymbol{n}=\mathbf{2 3})\end{array}$ & \multicolumn{2}{c}{$\begin{array}{c}\text { Statistical } \\
\text { analysis }\end{array}$} \\
\cline { 4 - 6 } & $\mathbf{( n = 2 7 )}$ & & $\mathbf{Z}$ & $\mathbf{p}$ \\
\hline $\mathrm{C} 3(\mathrm{~g} / \mathrm{l})$ & $0.965 \pm 0.103$ & $0.788 \pm 0.082$ & 4.075 & $<0.001$ \\
$\mathrm{C} 4(\mathrm{~g} / \mathrm{l})$ & $0.139 \pm 0.015$ & $0.105 \pm 0.004$ & 4.199 & $<0.001$ \\
$\mathrm{CRP}(\mathrm{mg} / \mathrm{l})$ & $3.57 \pm 0.37$ & $35.7 \pm 4.59$ & 4.197 & $<0.001$ \\
Leucocytic count $\left(10^{3} / \mu \mathrm{l}\right)$ & $5.26 \pm 0.4$ & $4.27 \pm 0.6$ & 4.198 & $<0.001$ \\
Neutrophil count $\left(10^{\mathbf{3}} / \mu \mathrm{l}\right)$ & $3.62 \pm 0.75$ & $3.08 \pm 0.76$ & 2.981 & 0.003 \\
Monocyte count $\left(10^{3} / \mu \mathrm{l}\right)$ & $0.454 \pm 0.07$ & $0.3 \pm 0.07$ & 3.917 & $<0.001$ \\
Lymphocyte count $\left(10^{3} / \mu \mathrm{l}\right)$ & $1.186 \pm 0.54$ & $0.886 \pm 0.152$ & 3.076 & 0.002 \\
Anti-dsDNA antibodies $(\mathrm{IU} / \mathrm{ml})$ & $19.4 \pm 4.13$ & $164.22 \pm 35.56$ & 4.197 & $<0.001$ \\
\hline
\end{tabular}

$\mathrm{P}$ value $<0.05$ was considered statistically significant.

Table (2): Mean ( \pm SD) of estimated STRAIL in SLE patients categorized disease according to activity in comparison to other studied patients and control group

\begin{tabular}{|c|c|c|c|c|}
\hline \multirow{2}{*}{\multicolumn{2}{|c|}{ Group }} & \multirow{2}{*}{ Serum sTRAIL $(\mathrm{pg} / \mathrm{ml})$} & \multicolumn{2}{|c|}{ Statistical analysis } \\
\hline & & & $Z$ & $p$ \\
\hline \multicolumn{2}{|c|}{ Control $(n=10)$} & $353.1 \pm 63.6$ & & \\
\hline \multicolumn{2}{|c|}{ RA $(n=15)$} & $414.3 \pm 50.2$ & 1.784 & $P_{1}>0.05$ \\
\hline \multirow{2}{*}{\multicolumn{2}{|c|}{ WG $(n=15)$}} & $378.1 \pm 32.7$ & 1.172 & $\mathrm{P}_{1}>0.05$ \\
\hline & & & 1.988 & $\mathrm{P}_{2}>0.05$ \\
\hline \multirow[t]{10}{*}{ SLE } & Total $(n=50)$ & $913.1 \pm 59.4$ & 2.805 & $\mathrm{P}_{1}=0.005$ \\
\hline & & & 3.408 & $\mathrm{P}_{2}=0.001$ \\
\hline & & & 3.408 & $\mathrm{P}_{3}=0.001$ \\
\hline & Active $(n=23)$ & $889.8 \pm 53.8$ & 2.805 & $\mathrm{P}_{1}=0.005$ \\
\hline & & & 3.408 & $P_{2}=0.001$ \\
\hline & & & 3.408 & $\mathrm{P}_{3}=0.001$ \\
\hline & Inactive & $932.9 \pm 57.6$ & 2.805 & $\mathrm{P}_{1}=0.005$ \\
\hline & $(n=27)$ & & 3.408 & $P_{2}=0.001$ \\
\hline & & & 3.408 & $\mathrm{P}_{3}=0.001$ \\
\hline & & & 3.052 & $\mathrm{P}_{4}=0.002$ \\
\hline
\end{tabular}

$P_{1}:$ significance versus control $\quad P_{2}:$ significance versus $R A$ patients

$P_{3}$ : significance versus $W G$ patients $P_{4}$ : significance versus active SLE patients

$\mathrm{P}$ value $<0.05$ was considered statistically significant. 
Table (3): Correlation coefficient " $r$ " between estimated sTRAIL in SLE patients and SLEDAI score and laboratory parameters of activity

\begin{tabular}{|c|c|c|}
\hline & "r" & $p$ \\
\hline SLEDAI score & -0.378 & $=0.007$ \\
\hline Anti-dsDNA (IU/ml) & -0.385 & $=0.006$ \\
\hline $\mathrm{CRP}(\mathrm{mg} / \mathrm{l})$ & -0.340 & $=0.016$ \\
\hline Neutrophil count $\left(10^{3} / \mu \mathrm{l}\right)$ & -0.332 & $=0.019$ \\
\hline
\end{tabular}

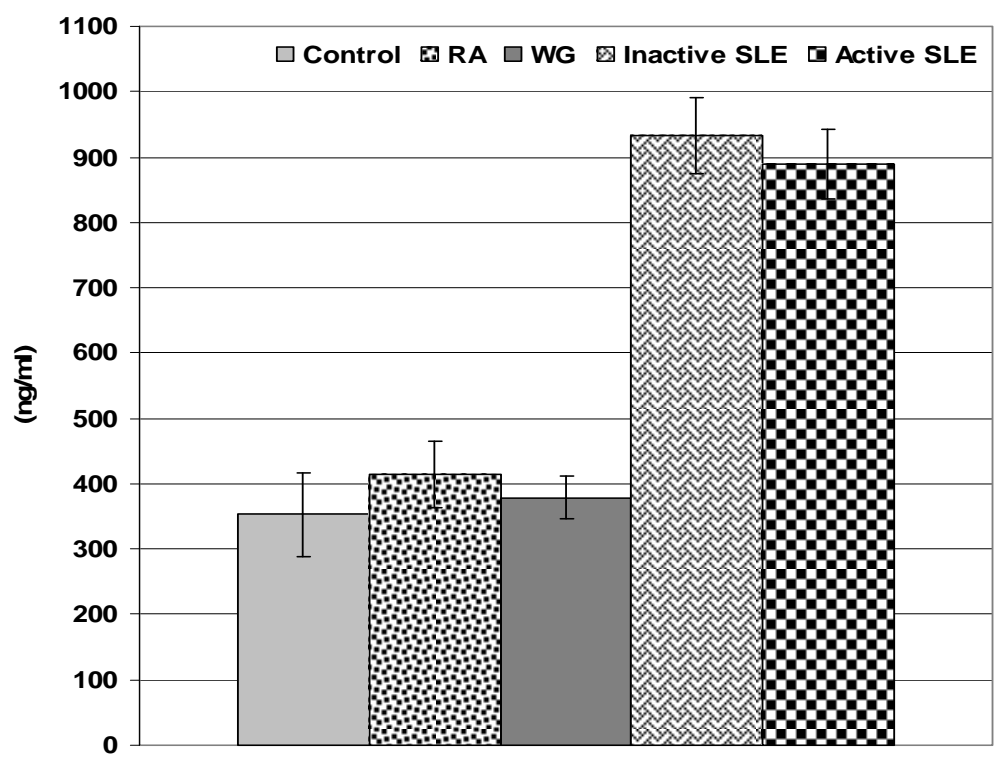

Fig. (1): Mean (+SD) of serum sTRAlL levels estimated in studied patients compared to control levels 

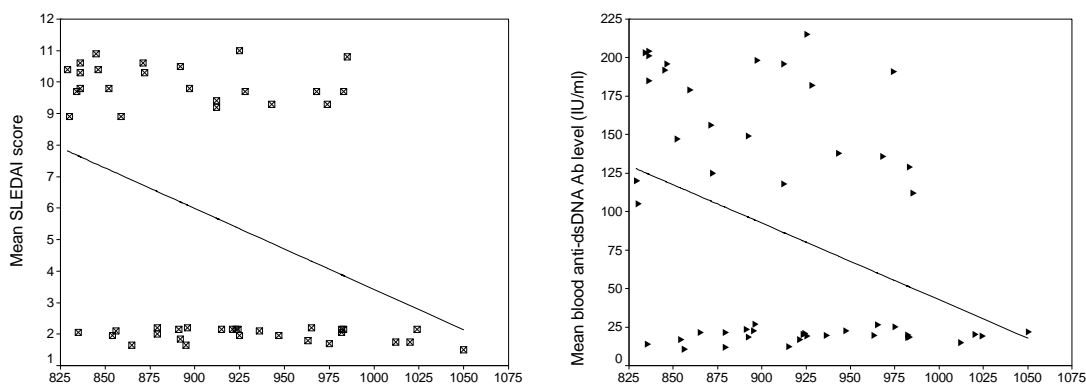

Mean serum level of STRAIL (pg/ml)

Mean serum STRAIL $(\mathrm{pg} / \mathrm{ml})$
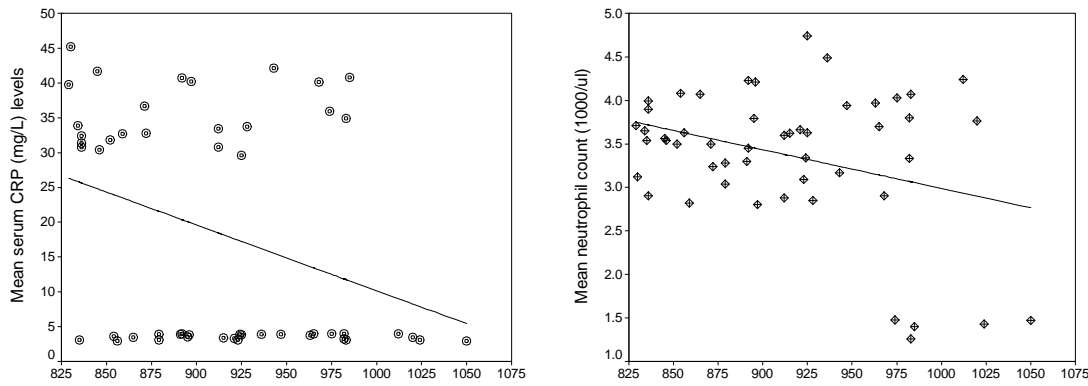

Mean serum level of sTRAIL $(\mathrm{pg} / \mathrm{ml})$

Mean serum levels of sTRAIL $(\mathrm{pg} / \mathrm{ml})$

Fig. (2): Correlation between mean serum levels of sTRAIL and SLEDAI score, anti-dsDNA antibodies, CRP and neutrophil count in SLE patients

\section{DISCUSSION}

Systemic lupus erythematosus is a prototypic systemic autoimmune disease characterized by dysregulation of cellular immune responses and reactivity of various endogenous antigens. The precise pathogenic mechanisms to clarify autoimmune phenomena remain partly unexplained. Both environmental initiating elements and genetic background play crucial roles in the pathogenesis of SLE. Functional dissecting studies of lupus with congenic mice models demonstrated that the individual gene locus on different chromosome regions affects specific immunological functions and contributes to pathogenic autoimmunity $^{(19)}$. Additionally, mice with apoptosis-related gene defects exhibit a number of characteristics that mimic SLE features and serological abnormality ${ }^{\mathbf{( 2 0 )}}$.

Apoptosis is a physiological process leading to the ordered elimination of cells and particularly the removal of autoreactive danger cells, averting inflammatory consequences by liberating intracellular contents ${ }^{(21)}$. SLE patients display accelerated apoptosis of circulating lymphocytes. The surplus of apoptotic cells and inadequate clearance of apoptotic cells mediated by phagocytes may be a source of autoantigens $^{(22)}$. Finally, the 
dissolution of self-tolerance by dysfunctional apoptotic pathways initiates B cell hyperactivity and consequent autoantibody overproduction $^{(23)}$.

TRAIL is a member of the TNF gene superfamily, which induces apoptosis through engagement of death receptors. TRAIL is unusual as compared to the other cytokines of this family, as it interacts with a complex system of receptors. Moreover, with respect to other members of the TNF superfamily, such as CD95L and TNF-alpha, TRAIL has generated great interest as a potential tumor-specific cancer therapeutic because as a stable soluble trimer it selectively induces apoptosis in many transformed cells but not in normal cells ${ }^{(24)}$.

The current study aimed to estimate the serum levels of soluble TRAIL in patients with SLE and to compare these levels to that estimated in patients with other autoimmune diseases and to control levels. Preliminary laboratory investigations defined significantly lower total and differential leucocytic counts in patients with active compared to those with quiescent disease and 5 patients were neutropenic.

These findings point to increased apoptosis of leucocytes and neutrophils during activity phase of disease and agreed with results of cellline study of Ren et al. ${ }^{\text {(22) }}$ who found that the percentage of apoptotic PMNs from patients with SLE was significantly higher than that of PMNs from healthy subjects and increased progressively with time of incubation and that serum from patients with SLE accelerated the rate of apoptosis in and secondary necrosis of PMNs from healthy subjects and macrophages from SLE patients were less capable of phagocytosing apoptotic PMNs compared with macrophages obtained from controls. They concluded that the observed increase of apoptotic PMNs and macrophages and the poor ability of macrophages from patients with SLE to phagocytose apoptotic bodies may indicate an impaired clearance mechanism, which may be mediated by factors in a patient's serum.

Various studies tried to explore the accelerated neutrophil apoptosis in active SLE; Armstrong et al. ${ }^{(\mathbf{2 5})}$ found neutrophils from SLE patients display resistance to the apoptosis-inhibiting effects of G-CSF and possibly GM$\mathrm{CSF}$, and appear more susceptible to the apoptosis-inducing action of TNF$\alpha$, the greatest resistance being observed in the more neutropenic patients. In another study, Armstrong et $\boldsymbol{a l}^{\mathbf{( 2 6 )}}$ attributed this to increased levels of anti-dsDNA antibodies and found polyclonal anti-dsDNA antibody isolated from the serum of patients with active SLE accelerates apoptosis in neutrophils from SLE patients as compared with neutrophils from healthy control or rheumatoid arthritis subjects. In support of such observation, in the current study there was a significant increase of blood levels of anti-dsDNA antibodies in patients with active compared to those with inactive SLE.

In another explanation, Lit et al. ${ }^{(27)}$ found a correlation of raised plasma concentration and ex vivo production of inflammatory chemokines with SLE disease activity, and their association with IL-18, 
supports the view that chemotaxis of Th1/Th2 lymphocytes and neutrophils is important in SLE pathogenesis.

Mean serum levels of sTRAIL were significantly higher in SLE patients, irrespective to the disease activity compared to serum levels estimated in controls $\left(\mathrm{P}_{1}=0.005\right)$ and in RA and WG patients $\left(\mathrm{P}_{2} \&\right.$ $\left.\mathrm{P}_{3}=0.001\right)$. On contrary, serum sTRAIL levels estimated in RA and WG were non-significantly higher compared to control level $\left(\mathrm{P}_{1}>0.05\right)$ with a non-significantly higher levels in RA patients compared to levels estimated in WG patients $\left(\mathrm{P}_{2}>0.005\right)$. These findings illustrated the specificity of increased serum levels of STRAIL to SLE disease as the levels estimated in patients with other autoimmune diseases were nonsignificantly different from control levels and in-between both types of diseases. Moreover, the obtained data spotted light on a possible role of TRAIL in pathogenesis of SLE.

These data go in hand with Komatsuda et al. ${ }^{(28)}$ who found the mean TRAIL mRNA expression level and serum sTRAIL concentration in SLE patients were significantly higher than those in healthy controls. They concluded that increased expression of TRAIL mRNA in peripheral blood mononuclear cells (PBMC) closely correlates with SLE activity and suggests an important role for TRAIL in the pathogenesis of SLE. Also, Castellino et al. ${ }^{(29)}$ found serum TRAIL and OPG concentrations in SLE patients were significantly higher than those in healthy volunteers.

The origin of the increased serum sTRAIL levels in SLE patients is still a mater of controversy; peripheral blood lymphocytes are activated in SLE patients even during clinically inactive disease; $T$ cell activation has been found to contribute to increased expression of TRAIL and other apoptotic ligands on lupus $\mathrm{T}$ cells isolated from SLE patients (11). Furthermore, in vitro studies reported that TRAIL could be released from stimulated monocytes $^{(30)}$ as well as from activated $\mathrm{T}$ cells, ${ }^{(31)}$. These findings are supported by increased gene expression of TRAIL and its decoy receptors in peripheral blood mononuclear cells from SLE patients ${ }^{(32)}$. This overexpression could result in increased TRAIL concentrations.

Interferons (IFN- $\alpha, \beta$ and $\gamma$ ) might also play an important role in increased sTRAIL levels; overexpression of IFN induced genes occurs in PBMC of SLE patients. This is of interest as human monocytes rapidly express TRAIL following activation with $\mathrm{IFN}^{(33)}$. Kirou et al. ${ }^{(34)}$ found SLE patients with a high IFN- $\alpha$ score had a significantly higher SLEDAI scores and disease activity, as measured by lower C3 levels, hemoglobin levels, absolute lymphocyte counts, and albumin levels, and a higher dsDNA titer. In support of these data, we reported significantly lower C3 and C4 levels in patients with active disease compared to levels estimated in patients with inactive disease. Also, Bijl et al. ${ }^{(35)}$ found that reduced uptake of apoptotic cells by monocytesderived macrophages from patients with SLE and subsequent disease activity is serum dependent and associated with decreased levels of $\mathrm{C} 4$ and $\mathrm{C} 3$. 
There was a negative significant correlation between serum sTRAIL and leucocytic and neutrophil counts, such data indicated a possible role for TRAIL in neutrophil apoptosis associated with SLE activity and agreed with Matsuyama et al. ${ }^{(\mathbf{3 6})}$ who found serum TRAIL levels in SLE patients with neutropenia were significantly higher than those of SLE patients without neutropenia and healthy volunteers and showed a significant negative correlation with neutrophil counts in SLE patients.

Patients with inactive SLE had a significantly $\left(\mathrm{P}_{4}=0.002\right)$ higher serum levels of sTRAIL compared to levels estimated in patients with active SLE. This could be attributed to binding of TRAIL to its receptors, distribution of sTRAIL throughout the body, or decreased TRAIL production. Binding of sTRAIL to its death receptors could lead to increased apoptosis of monocytes and lymphocytes. This is supported by the reported significantly decreased monocyte and lymphocyte counts found in patients with active SLE

It could be concluded that TRAIL has a possible role in pathogenesis and intiation of activity of SLE and estimation of serum sTRAIL could be used as a specific marker for differentiation between SLE from other autoimmune diseases and between patients with active and inactive disease.

\section{REFERENCES}

1. Choi JW (2006): Associations of Fas (CD95), tumor necrosis factor (TNF)-related apoptosis-inducing ligand (TRAIL), and biochemical manifestations in elderly persons. Clin Chim Acta.; 365(12):113-8

2. Wiley SR, Schooley K, Smolak PJ, Din WS, Huang CP \& Nicholl JK (1995): Identification and characterization of a new member of the TNF family that induces apoptosis. Immunity; 3:673-82

3. LeBlanc HN \& Ashkenazi A (2003): Apo2L/TRAIL and its death and decoy receptors. Cell Death Differ.;10:66-75

4. Baetu TM \& Hiscott J (2002): On the TRAIL to apoptosis. Cytokine Growth Factor Rev. 13, 199-207

5. Truneh A, Sharma S, Silverman C, Khandekar S, Reddy MP, Deen KC, McLaughlin MM, Srinivasula SM, Livi GP, Marshall, LA, Alnemri ES, Williams WV \& Doyle ML (2000): Temperaturesensitive differential affinity of TRAIL for its receptors. DR5 is the highest affinity receptor. J. Biol. Chem. 275, 23319-23325

6. Kim HS, Chang I, Kim JY, Choi KH \& Lee MS (2005): Caspase-mediated p65 cleavage promotes TRAILinduced apoptosis. Cancer Res.; 65(14):6111-9.

7. Rajagopalan S, Somers EC, Brook RD, Kehrer C, Pfenninger D, Lewis E, Chakrabarti A, Richardson BC, Shelden E, McCune WJ \& Kaplan MJ (2004): Endothelial cell apoptosis in systemic lupus erythematosus: a common pathway for abnormal vascular function and thrombosis 
propensity. Blood; $103 \quad$ (10): 3677-83.

8. Cross SS, Harrison RF, Balasubramanian SP, Lippitt JM, Evans CA, Reed MW \& Holen I (2006): Expression of receptor activator of nuclear factor kappabeta ligand (RANKL) and tumour necrosis factor related, apoptosis inducing ligand (TRAIL) in breast cancer, and their relations with osteoprotegerin, oestrogen receptor, and clinicopathological variables. J Clin Pathol.; 59(7): 716-20.

9. Huang WX, Huang P, Gomes A \& Hillert J (2000): Apoptosis mediators FasL and TRAIL are upregulated in peripheral blood mononuclear cells in MS. Neurology; 55:928-34.

10. Matsumura $R$, Umemiya $K$, Kagami M, Tomioka H, Tanabe E \& Sugiyama T (2002): Expression of TNF-related apoptosis inducing ligand (TRAIL) on infiltrating cells and of TRAIL receptors on salivary glands in patients with Sjogren's syndrome. Clin Exp Rheumatol;20:791-8

11. Kaplan MJ, Lewis EE, Shelden EA, Somers E, Pavlic $R$ \& McCune WJ (2002): The apoptotic ligands TRAIL, TWEAK, and Fas ligand mediate monocyte death induced by autologous lupus $\mathrm{T}$ cells. $\mathrm{J}$ Immunol;169:6020-9

12. Rus V, Atamas SP, Shustova V, Luzina IG, Selaru F \& Magder LS (2002): Expression of cytokine- and chemokine-related genes in peripheral blood mononuclear cells from lupus patients by cDNA array. Clin Immunol; 102:283-90.

13. Mok CC \& Lau CS (2003): Pathogenesis of systemic lupus erythematosus. J Clin Pathol.; 56: 481-90

14. Hoffman RW (2004): $T$ cells in the pathogenesis of systemic lupus erythematosus. Clin Immunol.; 113:4-13.

15. Bombardier C, Gladman DD, Urowitz MB, Caron D \& Chang CH (1992): Derivation of the SLEDAI. A disease activity index for lupus patients. The Committee on Prognosis Studies in SLE. Arthritis Rheum;35:630-40

16. Palmblad J, Papadaki HA \& Eliopoulos G (2001): Acute and chronic neutropenias: what is new? J Intern Med.; 250: 476-91.

17. Derksen RH, Bast EJ, Strooisma T \& Jacobs JW (2002): A comparison between the Farr radioimmunoassay and a new automated fluorescence immunoassay for the detection of antibodies against double stranded DNA in serum. Ann Rheumatic Diseases; 61: 1099102.

18. Ashkenazi A, et al. (1999): Safety and antitumor activity of recombinant soluble Apo2 ligand. J. Cli. Invest. 104: 155-162.

19. Wakeland EK, Liu K, Graham RR \& Behrens TW (2001): Delineating the genetic basis of systemic lupus erythematosus. Immunity.; 15:397-408

20. Mevorach D (2003): Systemic lupus erythematosus and apoptosis: a question of 
balance. Clin Rev Allergy Immunol.; 25(1):49-60.

21. Ou D, Wang $X$, Metzger DL, Robbins M, Huang J, Jobin C, Chantler JK, James RF, Pozzilli $P$ \& Tingle AJ (2005): Regulation of TNFrelated apoptosis-inducing ligandmediated death-signal pathway in human beta cells by Fasassociated death domain and nuclear factor kappa B. Hum Immunol.; 66(7):799-809.

22. Ren Y, Tang J, Mok MY, Chan AW, Wu A \& Lau CS (2003): Increased apoptotic neutrophils and macrophages and impaired macrophage phagocytic clearance of apoptotic neutrophils in systemic lupus erythematosus. Arthritis Rheum.; 48(10):288897.

23. Lesiak A, Sysa-Jedrzejowska A, Narbutt J, Lukamowicz J, Robak E \& Wozniacka A (2005): Proinflammatory cytokines in inactive lupus erythematosus patients. Przegl Lek.; 62 (9):838-42.

24. Secchiero $P$, Vaccarezza $M$, Gonelli A \& Zauli G (2004): TNF-related apoptosisinducing ligand (TRAIL): a potential candidate for combined treatment of hematological malignancies. Curr Pharm Des.; 10(29):3673-81.

25. Armstrong DJ, Whitehead EM, Crockard AD \& Bell AL (2005): Distinctive effects of GCSF, GM-CSF and TNFalpha on neutrophil apoptosis in systemic lupus erythematosus. Clin Exp Rheumatol.; 23(2):152-8.
26. Armstrong DJ, Crockard AD, Wisdom BG, Whitehead EM \& Bell AL (2006): Accelerated apoptosis in SLE neutrophils cultured with anti-dsDNA antibody isolated from SLE patient serum: a pilot study. Rheumatol Int.; 27(2):153156.

27. Lit LC, Wong CK, Tam LS, Li EK \& Lam CW (2006): Raised plasma concentration and ex vivo production of inflammatory chemokines in patients with systemic lupus erythematosus. Ann Rheum Dis.; 65(2): 209-15.

28. Komatsuda A, Wakui H, Iwamoto K, Togashi M, Maki N, Masai R, Hatakeyama $T \&$ Sawada K (2007): Up-regulation of TRAIL mRNA expression in peripheral blood mononuclear cells from patients with active systemic lupus erythematosus. Clin Immunol.; 125(1):269.

29. Castellino G, Corallini F, Trotta F \& Secchiero $P$ (2007): Elevated levels of TRAIL in systemic lupus erythematosus are associated to the presence of anti-SSA/SSB antibodies. Lupus.; 16(7):479-82.

30. Halaas O, Vik R, Ashkenazi A \& Espevik $T$ (2000): Lipopolysaccharide induces expression of APO2 ligand/TRAIL in human monocytes and macrophages. Scand J Immunol; 51:244-50

31. Monleon I, Martinez-Lorenzo MJ, Monteagudo L, Lasierra P, Taules $M$ \& Iturralde $M$ (2001): Differential secretion of 
Fas ligand- or APO2 ligand/TNFrelated apoptosis-inducing ligandcarrying microvesicles during activation-induced death of human $\mathrm{T}$ cells. $\mathrm{J}$ Immunol; 167:6736-44

32. Bijl M, Horst G, Limburg PC \& Kallenberg CG (2001): AntiCD3-induced and anti-Fasinduced apoptosis in systemic lupus erythematosus (SLE). Clin Exp Immunol;123:127-32

33. Bennett L, Palucka AK, Arce E, Cantrell V, Borvak $\mathbf{J} \&$ Banchereau J (2003): Interferon and granulopoiesis signatures in systemic lupus erythematosus blood. J Exp Med.; 197:711-23.

34. Kirou KA, Lee C, George S, Louca K, Peterson MG \& Crow MK (2005): Activation of the interferon-alpha pathway identifies a subgroup of systemic lupus erythematosus patients with distinct serologic features and active disease. Arthritis Rheum.; 52(5):1491-503.

35. Bijl M, Reefman E, Horst G, Limburg PC \& Kallenberg CG (2006): Reduced uptake of apoptotic cells by macrophages in systemic lupus erythematosus: correlates with decreased serum levels of complement. Ann Rheum Dis.; 65(1):57-63.

36. Matsuyama $W$, Yamamoto $M$, Higashimoto I, Oonakahara $\mathrm{K}$, Watanabe $M$, Machida $K$, Yoshimura T, Eiraku N, Kawabata M, Osame M \& Arimura K (2004): TNF-related apoptosis-inducing ligand is involved in neutropenia of systemic lupus erythematosus Blood; 104 (1): 184-91. 
دور محتمل للرابط المحفز للموت المبرمج للخلايا والمتعلق بعامل التنكرز

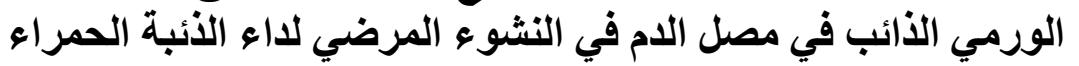

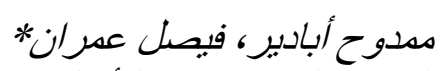

أقسـام الكيمياء الحيوية الطبية، الروماتيزم و التأهيل * ـكلية الطب ـ جامعة بنها

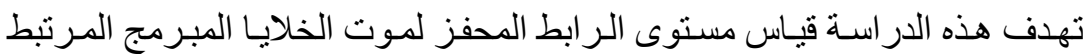

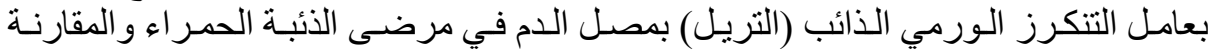

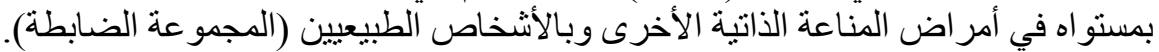

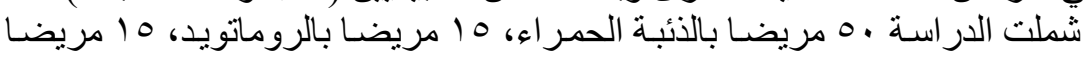

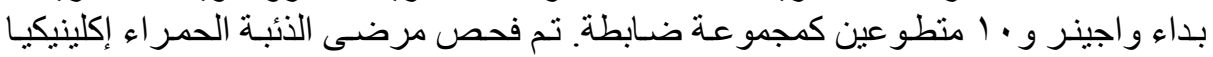

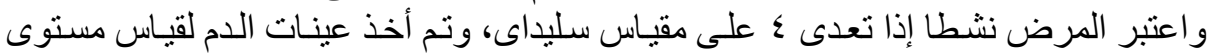

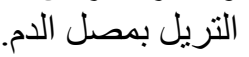

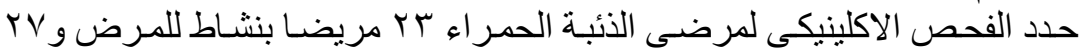

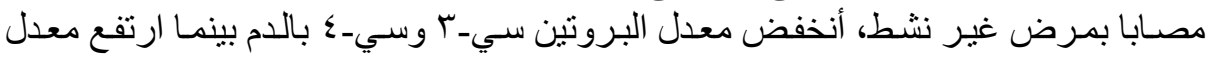

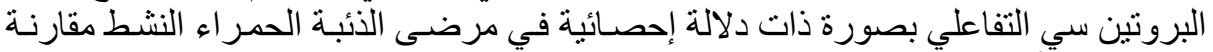

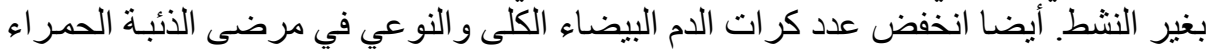

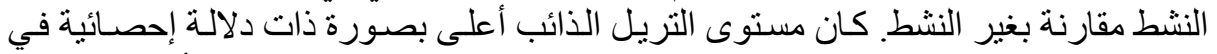

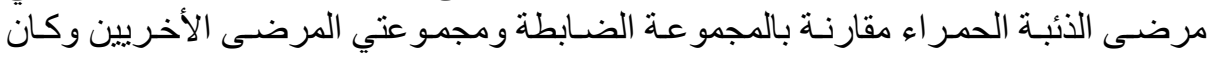

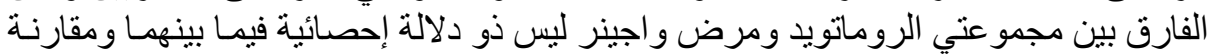

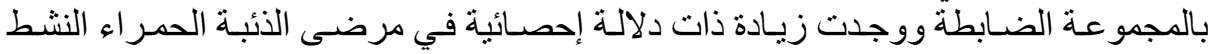

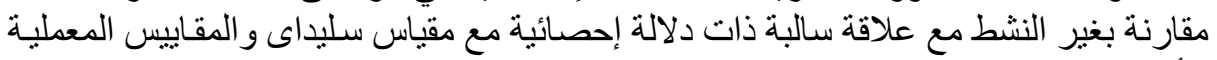

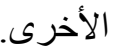

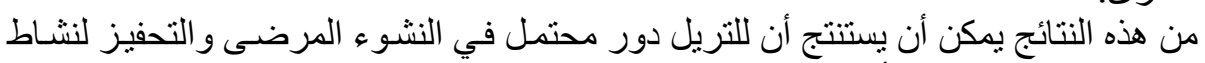

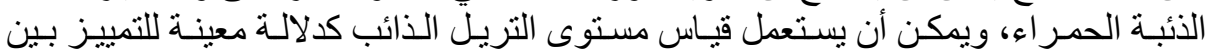

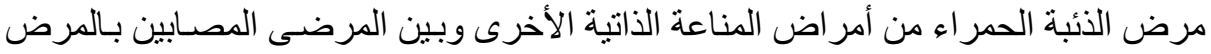

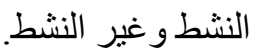

